\title{
Empirical Study Investation Intention Students
}

\author{
Hifzhan Frima Thousani ${ }^{1}$, Ridho Muarief ${ }^{2}$, Eva Mirza Syafitri ${ }^{3}$ \\ Politeknik Negeri Madiun, Jl. Serayu No.84, Kota Madiun ${ }^{1,2,3}$ \\ \{thousani@pnm.ac.id ${ }^{1}$ \}
}

\begin{abstract}
One individual who has the potential to invest in the capital market is a student. Along with the various subjects studied in lectures, students are also provided with knowledge that is related to investment. So that the 3 knowledge about or related to investment can be understood properly, students can carry out real activities, namely participating in investing in the capital market. One of the roles of students in society is as an agent of change. Students themselves have a great influence and have a very important position in the process of advancing science, including publicizing the importance of investing in the capital market to the public. Over time, the capital market will continue to grow and develop significantly. At this time students began to have an interest or interest in investing. However, there are still obstacles to be faced, especially for those who are new or who are about to start the investment. The obstacles faced are in the form of not understanding the procedures or risks when investing. The existence of these obstacles hampers investment interest. This is the factor of interest in investing to be discussed in this study. This research uses quantitative methods. Contains research objects, population and samples, types and sources of data, data collection methods, research variables, and analysis tools. TKT in this research is TKT 1-3 intended for Research for Beginner Lecturers. The targeted output is a national journal accredited level 1-6.
\end{abstract}

Keywords: Investment, student, D3 Madiun State Polytechnic Business Administration

\section{Intoduction}

In recent years, interest in investing has increased. In the beginning, investments were only made by a few groups such as entrepreneurs, business people, and some people who have interests. However, over the years, many people are interested in investing. Indeed, when compared to other countries, the number of investors in Indonesia compared to the population is still relatively small. But over the years, the number of investors has also increased.

Investment can be defined as investment in an activity that has a relatively long term in various business fields [1]. Investments that are invested in the narrow sense are in the form of certain projects, both physical and non-physical. Based on the assets, investment is divided into two, namely real assets such as land, gold, houses and financial assets such as deposits, stocks, bonds, and other securities. A person who makes an investment is called an investor. The main objective of investors to invest is to obtain profits [2]. Investors buy a stock today and expect to get a profit and increase in the stock at a later date. However, not all of the 
benefits obtained were as previously expected. The type of investment chosen will affect the rate of return. Stock investing can offer higher returns than investing in deposits.

According to [3], there are two paradigms that apply regarding investment in society. First, investment is seen as a desire. This occurs when a person has excess money and it is saved as savings rather than invested. The money will only be distributed to investment instruments when the owner of the money has the desire to invest. Second, investment is seen as a necessity. This occurs when someone has excess money and is immediately used for investing rather than saving. Money owners are very aware of the importance of investing for the future. If there is inflation, the value of money invested will also increase in line with the inflation rate.

Students can be a big potential as investors in the new capital market. It cannot be denied that students are one of the most attractive young prospective investors because they have a basic investment knowledge that has been given since entering the world of lectures [4]. Investment knowledge is very important for potential investors to have before investing by spending funds or other investment instruments.

The knowledge that a person has regarding capital market investment is a provision for investing. A potential investor must find out about information and knowledge about investment procedures in order to be prepared and be able to minimize the risks that will occur. In addition, potential investors can adjust themselves according to financial needs. Someone who has an understanding of investing and understands the risks that may occur when investing can influence one's interest in investing in the capital market.

A student has several factors that can influence his investment. The main factor in investing is intention. Intention can show how much a person dares to try and show how hard a person is planning to do something. Intention also determines how a person will behave in the future. To achieve success in anything, a human being needs a serious and earnest intention to do something.

In general, investing requires capital. For an entrepreneur and businessman, capital is not an obstacle. It is different if a student will make an investment. Not all students come from families that are wealthy or have an adequate economy. Some students come from families with low economic levels, there are also students who have to live independently by migrating and bear their own expenses. Such economic conditions can become an obstacle for a student to invest because they do not have sufficient capital to invest, especially when considering the risks that will occur. Student financial sources can come from parental gifts, scholarships, or from personal income. However, currently, the terms and conditions for opening an investment account are relatively straightforward. With some securities, the initial funds used to create an account are only around IDR 100,000.00. This initial paid-up capital does not have to be fully spent. There are facilities provided by the securities and it is hoped that they will be able to increase public interest, especially in the capital market.

The biggest investment factor is motivation. Motivation can grow from yourself as well as from others. Someone who has the will tends to try to find information about the capital market and study hard. Motivation that comes from the outside environment comes from encouragement given by experienced motivators related to investment and capital markets. Other people can help someone else to motivate. Students who act as agents of change can act as motivators for others. By publishing the importance of investing in the capital market, it will certainly increase public interest in investing. In addition, students can provide education about the importance of the capital market to the public. This will make the capital market continue to grow and develop significantly. 
Return is the result obtained from investing in investment. Returns can be in the form of realized returns that have occurred or expected returns that have not occurred but are expected to occur in the future [5]. Return is related to risk, the higher the risk taken, the higher the expected return.

Risk is something that everyone who will invest in is afraid of. But everyone is different in dealing with and accepting the risks that will occur. In investing, besides considering the return that will be received, risks also need to be considered. According to [5], risk is related to deviations or deviations from the accepted and expected outcomes.

In the previous discussion, it has been found that many factors can influence students to invest. However, the factors to be studied include knowledge, motivation, minimum capital, return, and risk perception among D3 students of Madiun State Polytechnic Business Administration Study Program.

\section{Method}

This research uses quantitative methods. Quantitative research is defined as a systematic investigation of phenomena by collecting data that can be measured through statistics, mathematics, or computation. In quantitative research, the theoretical paradigm is used to guide researchers in finding analysis of the factors of research problems, finding hypotheses, concepts, methodologies, and finding data analysis tools [6].

The research was conducted on Madiun State Polytechnic students, D3 Business Administration Study Program. Measurement variables used in research are factors that influence investing. The investment factors to be measured include knowledge, motivation, minimum capital, return, risk perception. Student investment interest will be the dependent variable and the investment factor will be the independent variable. The data will be obtained through a questionnaire filled out by the respondents. The variable measurement scale used is the ordinala scale which contains the answer preference level with the following choices: 1) Strongly disagree, 2) Agree, 3) Doubt, 4) Agree, 5) Strongly agree [7].

After all the respondent's data has been collected, the data will be inputted and processed through the SPSS program using the validity test, reliability test, normality test, partial t-test and simultaneous test. The hypothesis in this study is that the factors of knowledge, motivation, minimum capital, return, and risk perception do not affect students' interest in investing in the capital market.

\section{Result and Discussion}

In this study, data analysis was carried out using Principal Factor Analysis (PCA), which is to test the changing variables from most of the original variables used which correlate with one another into a new set of smaller and independent variables (not correlated anymore ).

Table 1. Principal Factor Analysis (PCA)

\begin{tabular}{cll}
\hline No. & Variable & \multicolumn{1}{c}{ Information } \\
\hline 1 & Interest & Student interest in investing \\
2 & Economy & Student Economic Conditions \\
3 & Endorsement & Investing support from those closest to you \\
4 & Needs & Investment needs in the long term \\
\hline
\end{tabular}




\subsection{KMO and Barlett's Test (Barleett's Test of Sphericity)}

Testing criteria are carried out by looking at the KMO (Kaiser-Meyer-Olkin) value, namely, measuring the adequacy of sampling (sampling adequacy). This index compares the magnitude of the observed correlation coefficient with the magnitude of the partial correlation coefficient. The small KMO value indicates that the correlation between pairs of variables cannot be explained by other variables. From the output below, you can see the KMO value of 0.521 (KMO value $>0.5)$.

Table 2. KMO and Bartlett's Test

\begin{tabular}{llr}
\hline Kaiser-Meyer-Olkin Measure of Sampling Adequacy. & .521 \\
Bartlett's Test of Sphericity & Approx. Chi-Square & 9,906 \\
& Df & 6 \\
& Sig. & .129 \\
\hline
\end{tabular}

\subsection{Measure of Sampling Adequancy (MSA) Test}

The results of the MSA test can be seen in table 4, as follows:

Table 3. KMO and Bartlett's Test

\begin{tabular}{cl}
\hline Variable & MSA \\
\hline Interest & 0.842 \\
Economy & 0.905 \\
Endorsement & 0,965 \\
Needs & 0.904 \\
\hline
\end{tabular}

Anti-image Matrices Measures of Sampling Adequacy (MSA) shows a value above 0.5, then a variable is formed that has a loading value $>0.5$. With this factor rotation process, it can be seen that the factors formed are 2 factors. This can be seen in Table $\mathrm{x}$, besides that in Table $\mathrm{x}$ shows the distribution of 4 variables in the 2 factors that have been formed.

Table 4. Rotated Component Matrix

\begin{tabular}{lcc}
\hline & \multicolumn{2}{c}{ Component } \\
\cline { 2 - 3 } & $\mathbf{1}$ & $\mathbf{2}$ \\
\hline Needs & .857 & -113 \\
Interest & .735 & .319 \\
Economy & .133 & .777 \\
Endorsement & & .703 \\
\hline
\end{tabular}

Table 5. Factor Groups

\begin{tabular}{lc}
\hline \multicolumn{1}{c}{ Variable } & Factor Group \\
\hline Needs & 1 \\
Interest & 1 \\
Economy & 2 \\
Endorsement & 2 \\
\hline
\end{tabular}

Based on Table 5, it can be stated that all existing factors have forming variables, namely as follows: a. Factor 1 has 2 forming variables, namely Needs and Interests variables. b. Factor 2 has 2 forming variables, namely the economic variable and support. 
Table 6. Forming Variables

\begin{tabular}{ccccc}
\hline No. & Variable & Factor & \% Variance & \% Cumulative \\
\hline 1 & Needs & 1 & 37,407 & 37,407 \\
2 & Interest & & & \\
3 & Economy & 2 & 25,265 & 62,672 \\
4 & Support & & & \\
\hline
\end{tabular}

Extraction analysis to determine factors. The factors formed are 2 factors, so the amount of variance in each factor is formed, namely:

a. Factor $1=37.407 \%$ from $100 \%$ of the variance, meaning that from $100 \%$ of the variance, only $37.407 \%$ of the variance can be explained by factor 1 based on the variability of factor 1.

b. Factor $2=25,265 \%$ of the $100 \%$ variance, meaning that from $100 \%$ of the variance, only $25,265 \%$ of the variance can be explained by factor 2 based on the variability of factor 2 .

The factors that are formed are 2 factors, then the cumulative number of each factor is formed, namely:

a. Factor $1=37.407 \%$ of the $100 \%$ cumulative amount, meaning that the cumulative factor 1 is 37,407 .

b. Factor $2=$ total (cumulative factor 1) $37,407+25,265$ (factor 2 variance) $=62,672$, meaning 62,672 cumulative that can be formed by factor 2 .

\section{Conclusion}

Based on the results of the main component analysis, it can be seen that the factors that most influence Student Investment intention can be categorized into 2 components. The first component, the variables belonging to the first component category are dominant with the desire to invest (interest) and the need to invest. Process factor 1 can explain the variance with the number $=37.40 \%$. Meanwhile, when viewed from the loading value, the variable that most influences the first factor is need with the highest correlation value $=0.857$. The second component, in this component there are variables that fall into the category, namely the Economic Condition and Support variables. This factor can explain the variance of the variance with a total $=25.265 \%$. Meanwhile, when viewed from the loading value, the variable that has the most influence on the second factor is the economic condition with the highest correlation value $=0.777$.

\section{References}

[1] Kasmir dan Jakfar, Studi Kelayakan Bisnis. Jakarta: Kencana prenada media group, 2013.

[2] Syahyunan, Perencanaan, Analisis dan Pegendalian Keuangan, Kedua. Medan, Sumatera Utara: USU Press, 2013.

[3] M. B. A. Kadir, M. Salim, and H. Kamarudin, "The Relationship Between Educational Support and Entrepreneurial Intentions in Malaysian Higher Learning Institution," Procedia - Soc. Behav. Sci., vol. 69, no. Iceepsy, pp. 2164-2173, 2012, doi: 10.1016/j.sbspro.2012.12.182.

[4] H. Hermanto, "Perilaku Mahasiswa Ekonomi Di Universitas Esa Unggul Dalam Melakukan Investasi Di Pasar Modal,” J. Ekon. Univ. Esa Unggul, vol. 8, no. 01, p. 
$79445,2017$.

[5] Jogiyanto, Teori Portofolio dan Analisis Investasi, Ketujuh. Yogyakarta: BPFE, 2010.

[6] B. Bungin, Analisa Data Penelitian Kualitatif. Jakarta: Prenada Media Group, 2008.

[7] Yusrizal, "Analysis of difficulty level of physics national examination's questions," $J$. Pendidik. IPA Indones., vol. 5, no. 1, pp. 140-149, 2016, doi: 10.15294/jpii.v5i1.5803. 